University of Nebraska - Lincoln

DigitalCommons@University of Nebraska - Lincoln

Faculty Publications: Department of

Entomology

Entomology, Department of

August 2005

\title{
Flight Behavior of Methyl-Parathion-Resistant and -Susceptible Western Corn Rootworm (Coleoptera: Chrysomelidae) Populations from Nebraska
}

\author{
Jenny A. Stebbing \\ University of Nebraska-Lincoln \\ Lance J. Meinke \\ University of Nebraska-Lincoln, Imeinke1@unl.edu \\ Steve E. Naranjo \\ University of Nebraska-Lincoln \\ Blair Siegfried \\ University of Nebraska-Lincoln, bsiegfried1@ufl.edu \\ Robert J. Wright \\ University of Nebraska-Lincoln, rwright2@unl.edu
}

See next page for additional authors

Follow this and additional works at: https://digitalcommons.unl.edu/entomologyfacpub

Part of the Entomology Commons

Stebbing, Jenny A.; Meinke, Lance J.; Naranjo, Steve E.; Siegfried, Blair; Wright, Robert J.; and Chandler, Laurence D., "Flight Behavior of Methyl-Parathion-Resistant and -Susceptible Western Corn Rootworm (Coleoptera: Chrysomelidae) Populations from Nebraska" (2005). Faculty Publications: Department of Entomology. 47.

https://digitalcommons.unl.edu/entomologyfacpub/47

This Article is brought to you for free and open access by the Entomology, Department of at DigitalCommons@University of Nebraska - Lincoln. It has been accepted for inclusion in Faculty Publications: Department of Entomology by an authorized administrator of DigitalCommons@University of Nebraska - Lincoln. 


\section{Authors}

Jenny A. Stebbing, Lance J. Meinke, Steve E. Naranjo, Blair Siegfried, Robert J. Wright, and Laurence D. Chandler 


\title{
Flight Behavior of Methyl-Parathion-Resistant and -Susceptible Western Corn Rootworm (Coleoptera: Chrysomelidae) Populations from Nebraska
}

\author{
JENNY A. STEBBING, LANCE J. MEINKE, ${ }^{1}$ STEVE E. NARANJO, ${ }^{2}$ BLAIR D. SIEGFRIED, \\ ROBERT J. WRIGHT, AND LAURENCE D. CHANDLER ${ }^{3}$
}

Department of Entomology, University of Nebraska-Lincoln, 202 Plant Industry, Lincoln, NE 68583-0816

\begin{abstract}
J. Econ. Entomol. 98(4): 1294-1304 (2005)
ABSTRACT Relative flight behavior of methyl-parathion-resistant and -susceptible western corn rootworm, Diabrotica virgifera virgifera LeConte populations, was studied as part of a larger effort to characterize the potential impact of insecticide resistance on adult life history traits and to understand the evolution and spread of resistance. A computer interfaced actograph was used to compare flight of resistant and susceptible individuals, and flight of resistant individuals with and without prior exposure to methyl-parathion. In each case, mean trivial and sustained flight durations were compared among treatments. In general, there were few differences in trivial or sustained flight characteristics as affected by beetle population, insecticide exposure, sex, or age and there were few significant interactions among variables. Tethered flight activity was highly variable and distributions of flight duration were skewed toward flights of short duration. Tethered flight activity was similar among resistant and susceptible beetles with the exception that susceptible beetles initiated more flights per beetle than resistant beetles. After sublethal exposure to methyl-parathion, total flight time, total trivial flight time, and mean number of flights per resistant beetle declined significantly. Because long-range flight was uncommon, short- to medium-duration flights may play an important role in determining gene flow and population spread of resistant $D$. v. virgifera. These results suggest that organophosphate-resistant beetles can readily move and colonize new areas, but localized selection pressure (e.g., management practices) and exposure to methyl-parathion may contribute to the small-scale differences in resistance intensity often seen in the field.
\end{abstract}

KEY WORDS Diabrotica virgifera virgifera, dispersal, resistance management, movement

THE WESTERN CORN ROOTWORM, Diabrotica virgifera virgifera LeConte, is a widely distributed insect pest of field corn, Zea mays L., in the United States (Levine and Oloumi-Sadeghi 1991). Adults are univoltine, and larvae can only survive on selected grass species (Branson and Ortman 1970). The continued presence of populations at a particular site and colonization of new habitats are dependent on adult dispersal and ovipositional behaviors.

Adult western corn rootworms exhibit both trivial and sustained flight behaviors (Coats et al. 1986; Naranjo 1990, 1991), although most flights are of short duration (classified as trivial, Coats et al. 1986, Naranjo 1990). Sustained flight has been characterized in laboratory studies as flight duration longer than $20 \mathrm{~min}$

This article presents the results of research only. Mention of a proprietary product does not constitute endorsement or recommendation by USDA for its use.

${ }^{1}$ Corresponding author, e-mail: lmeinkel@unl.edu.

${ }^{2}$ Western Cotton Research Laboratory, USDA-ARS, 4135 East Broadway Rd., Phoenix, AZ 85040.

${ }^{3}$ Natural Resources Research Center, USDA-ARS, 2150 Centre Ave., Fort Collins, CO 80526-8119.
(Naranjo 1990) or 30 min (Coats et al. 1986), and both sexes exhibit this behavior (Naranjo 1990). Sustained flight is conducted primarily by mated preovipositional females (Coats et al. 1986), but females as old as $30 \mathrm{~d}$ may exhibit sustained flight (Naranjo 1990). Coats et al. (1986) reported that tethered female beetles could fly continuously for up to $4 \mathrm{~h}$ with the ability to travel up to $24 \mathrm{~km}$ in one flight.

In the field, western corn rootworm flight activity typically follows a bimodal pattern; peak activity occurs 2- $4 \mathrm{~h}$ after sunrise and before sunset (Witkowski et al. 1975, Isard et al. 2000). Laboratory studies also have shown that sustained flight is confined to the early morning and evening hours, but trivial flights occur throughout the day (Coats et al. 1986, Naranjo 1990). Grant and Seevers (1990), and Isard et al. (1999) found that a wide range of radiation loads, air temperatures, and wind speeds occur during peak periods of flight activity.

The mobility of the western corn rootworm enables adults to colonize new habitats (Godfrey and Turpin 1983, Grant and Seevers 1989) and has permitted the species to extend its range eastward from Nebraska in 
1955 (Chiang 1973) to New Jersey by 1983 (Krysan and Smith 1987). Studies of cyclodiene-resistant western corn rootworm populations have provided complementary evidence of this west-to-east movement. Cyclodiene-resistant western corn rootworm populations were first identified in Nebraska during 1959 1963 (Ball and Weekman 1963). In subsequent years, as the western corn rootworm expanded its range eastward, founder populations also were resistant to cyclodiene insecticides (Metcalf 1983). Before 1960, the western corn rootworm had increased its range $\approx 19-48 \mathrm{~km}$ per year; however, after the resistant strain evolved, the species moved 13-193 km per year (Metcalf 1986). Metcalf (1986) proposed that the increased rate of movement was somehow associated with an increase in fitness associated with the resistance gene.

Carbamate and organophosphate insecticides eventually replaced organochlorine insecticides and were used extensively by corn growers for rootworm control during the 1970s-1990s (Meinke et al. 1998). In areas of south central Nebraska, where adult management programs were adopted as an alternative to application of soil insecticides at planting, reports of insecticide control failures began to occur in the early 1990s. Recent studies have documented that western corn rootworm populations have become resistant to some carbamate and organophosphate insecticides in areas of Nebraska where adult management has been practiced for many years (Meinke et al. 1998, Miota et al. 1998, Scharf et al. 1999).

As part of a larger effort to characterize the potential impact of insecticide resistance on adult life history traits and to understand the evolution and spread of resistance, we evaluated the relative flight behavior of methyl-parathion-resistant and -susceptible western corn rootworm populations. This article reports the results of comparative tethered flight experiments conducted to contrast 1) resistant and susceptible beetles and 2) resistant beetles with and without prior exposure to methyl-parathion.

\section{Materials and Methods}

All flight testing was done with a computer-interfaced tethered flight system (Naranjo 1990). Beetles were anesthetized with $\mathrm{CO}_{2}$ (exposure time $<1 \mathrm{~min}$ ) and tethered by the pronotum with dental wax to the end of a piece of quilting thread. The other end of the thread was connected to a small copper tube ( 10 by 1 $\mathrm{mm}$ i.d.) fitted to the end of a lever as described below.

Tethered beetles were attached to one end of a balanced, lightweight lever, which pivots on a fulcrum, and had a small flag attached to the opposite end. An infrared beam was broken by the flag when an insect was at rest, which generated an electrical signal that was recorded by the computer. Beetles flew in a vertical plane and remained suspended above a substrate when not in flight. Beetles remained tethered for $23 \mathrm{~h}$.

The actograph was housed in a small empty laboratory, maintained at $23.5 \pm 1^{\circ} \mathrm{C}$ and $30 \pm 15 \% \mathrm{RH}$ with a photoperiod of 14:10 (L:D) h. The flight mill measured the duration of each flight, the clock time of flight initiation and termination, and the total number of flights over a 23-h period for each beetle.

Experiment 1: Flight Behavior of Resistant and Susceptible Beetles. The tethered flight device was used to compare the flight behavior of $F_{1}$ adults from methyl-parathion-resistant and -susceptible populations collected near Keene in Kearney County, Nebraska, and Concord in Dixon County, Nebraska, respectively (Meinke et al. 1998, Zhou et al. 2002). The resistant population was geographically located in south-central Nebraska where the highest levels of resistance have been recorded (i.e., resistant population $L D_{50}$ 16-fold greater than the $\mathrm{LD}_{50}$ of a susceptible population, Meinke et al. 1998). Larvae were reared on seedling corn in small plastic trays (100 by $15 \mathrm{~mm}$ ) until they reached second or third instar. Larvae were then transferred to larger plastic shoeboxes ( 31.5 by 19.5 by $11 \mathrm{~cm}$ ) with fresh corn seedlings to complete larval development and pupation (modified standard rearing procedures, Jackson 1985). Adults emerged and cohorts were placed into Plexiglas boxes $\left(30 \mathrm{~cm}^{3}\right)$ and provided a diet of corn ears, lettuce, and bee pollen for at least 24-48 h before shipment via FedEx to the USDA-ARS, Western Cotton Research Laboratory (Phoenix AZ) for flight studies. Upon arrival, beetles were allowed to feed on corn ears, lettuce, and bee pollen for at least $24 \mathrm{~h}$ before flight initiation. Beetles of each sex and from two age groups (3-10 d and $11-20 \mathrm{~d}$ postemergence) were assayed.

Experiment 2: Flight Behavior of Resistant Beetles Exposed to a Sublethal Dose of Methyl-Parathion. Relative flight activity of resistant beetles (Kearney Co. population) after exposure to a sublethal dose of methyl-parathion was compared with resistant beetles with no prior exposure to insecticide. Beetles were reared, provided specific diets, handled, and shipped as described previously. A 4-h vial bioassay (Meinke et al. 1997, Zhou et al. 2002) was used to expose cohorts of resistant beetles to a diagnostic concentration of methyl-parathion $(0.5-\mu \mathrm{g}$ vial). The inside surface of glass scintillation vials was coated with technical grade methyl-parathion in $0.5 \mathrm{ml}$ of acetone, and then vials were rolled until the insecticide dried $(\approx 0.5 \mathrm{~h})$. The diagnostic concentration was selected based on the dose-response curves of a representative resistant and susceptible population and falls within the susceptible $\mathrm{LC}_{99} 95 \%$ confidence interval (CI) at 4-h exposure. The diagnostic concentration kills $100 \%$ of beetles bioassayed from very susceptible field populations and $<8 \%$ of beetles from the most resistant Nebraska populations (L.J.M., unpublished; Zhou et al. 2002). In a preexperiment vial bioassay, the diagnostic concentration killed $100 \%(81 / 81)$ of the Dixon County population and $10.9 \%(11 / 101)$ of the Kearney County population. Beetles were anesthetized by chilling on ice and then placed in vials ( 10 per vial) and held at $22^{\circ} \mathrm{C}$ for $4 \mathrm{~h}$. Control insects were only exposed to acetone-treated vials. Beetles surviving the bioassay were allowed to feed on corn ears for $24 \mathrm{~h}$ before tethering to the flight mill to remove potential con- 


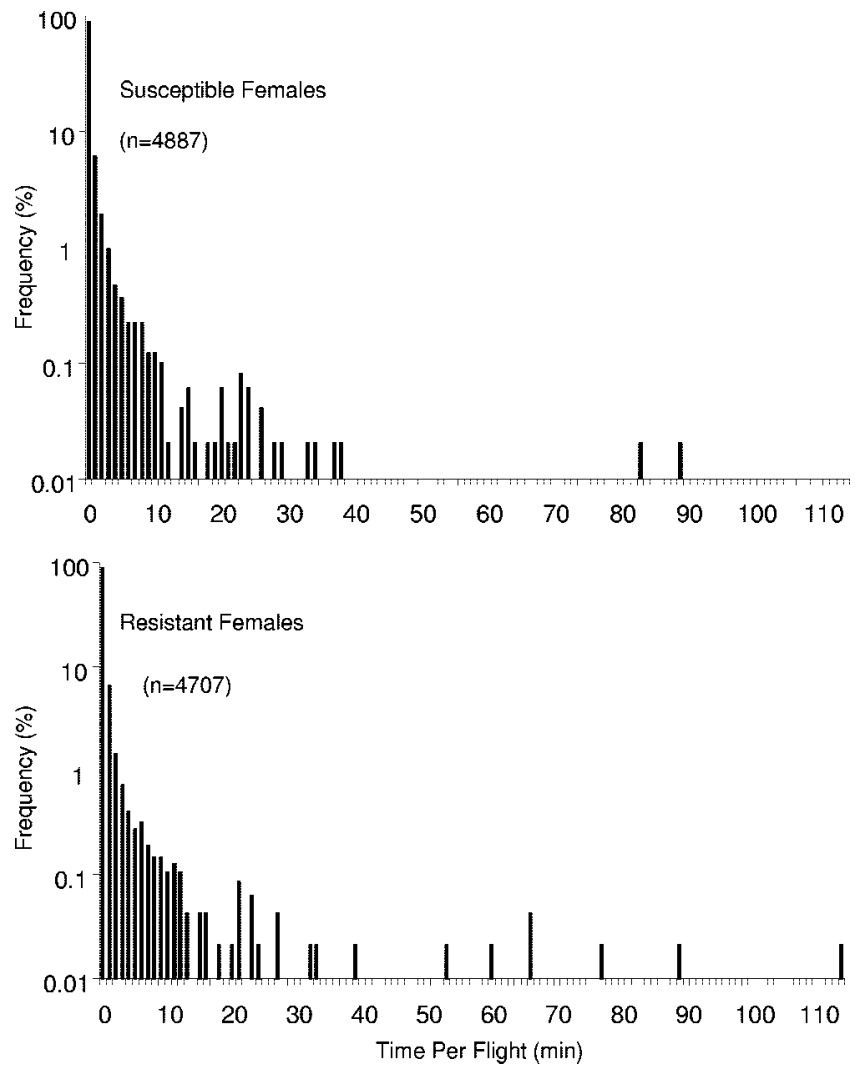

Fig. 1. Distributions of durations of all flights by susceptible $(n=54)$ and resistant $(n=64)$ female western corn rootworms. Note the logarithmic $y$-axis.

founding effects of confinement in vials. Beetles of each sex and from two age groups were assayed: 5-10 $\mathrm{d}$ and $11-20 \mathrm{~d}$ post emergence.

Statistical Analyses. Only data from beetles that engaged in one or more flights during $23 \mathrm{~h}$ were included in statistical analyses. Flight duration was characterized as "trivial" ( $>1 \mathrm{~min}<20 \mathrm{~min}$ ) or "sustained" (>20 min) based on previous tethered flight data reported for the western corn rootworm (Coats et al. 1986, Naranjo 1990). A three-way analysis of variance (ANOVA) implemented in PROC GLM (SAS Institute 1998) was used to analyze data from each experiment. In experiment 1 , main effects were population (resistant or susceptible), sex, and age (younger versus older adults); whereas in experiment 2 , main effects were insecticide exposure (exposed versus unexposed methyl-parathion-resistant adults), sex, and age (younger versus older adults). Flight parameters that were analyzed in each experiment included total number of flights, number of flights $<1$ min., number of trivial flights $>1$ min., number of sustained flights, total flight time, trivial flight time, and sustained flight time per beetle. When interactions among main effects were not significant in initial analyses, the ANOVA was repeated focusing only on main effects. Residual plots confirmed that the assumption of normality was reasonable; therefore, data were not transformed before analysis. To facilitate comparisons within each main effect, mean flight durations were calculated for each beetle for trivial and sustained flight parameters over all flights made by each individual in the 23-h assay period. It should be noted that beetles engaging in sustained flights also undertook trivial flights, and many individuals only exhibited trivial flight. A significance level of $P<0.05$ was used for all analyses.

\section{Results}

Experiment 1: Flight Behavior of Resistant and Susceptible Beetles. A similar percentage of resistant and susceptible tethered beetles took at least one flight (susceptible: 67.9\%, 108/159; resistant: 65.8\% 98/149), suggesting that there were no inherent differences among populations in the number of beetles that would typically fly in a 23-h period under tethered flight conditions. A total of 54 susceptible female beetles engaged in 4,887 flights, whereas 64 resistant female beetles undertook 4,707 flights (Fig. 1). A majority of these flights ( $88 \%$ for both susceptible and resistant strains) were $<1 \mathrm{~min}$ in duration. Male flight distribution patterns were similar to those exhibited by females (Fig. 2). Less than $0.5 \%$ of all female flights extended beyond the $20 \mathrm{~min}$ sustained flight threshold 

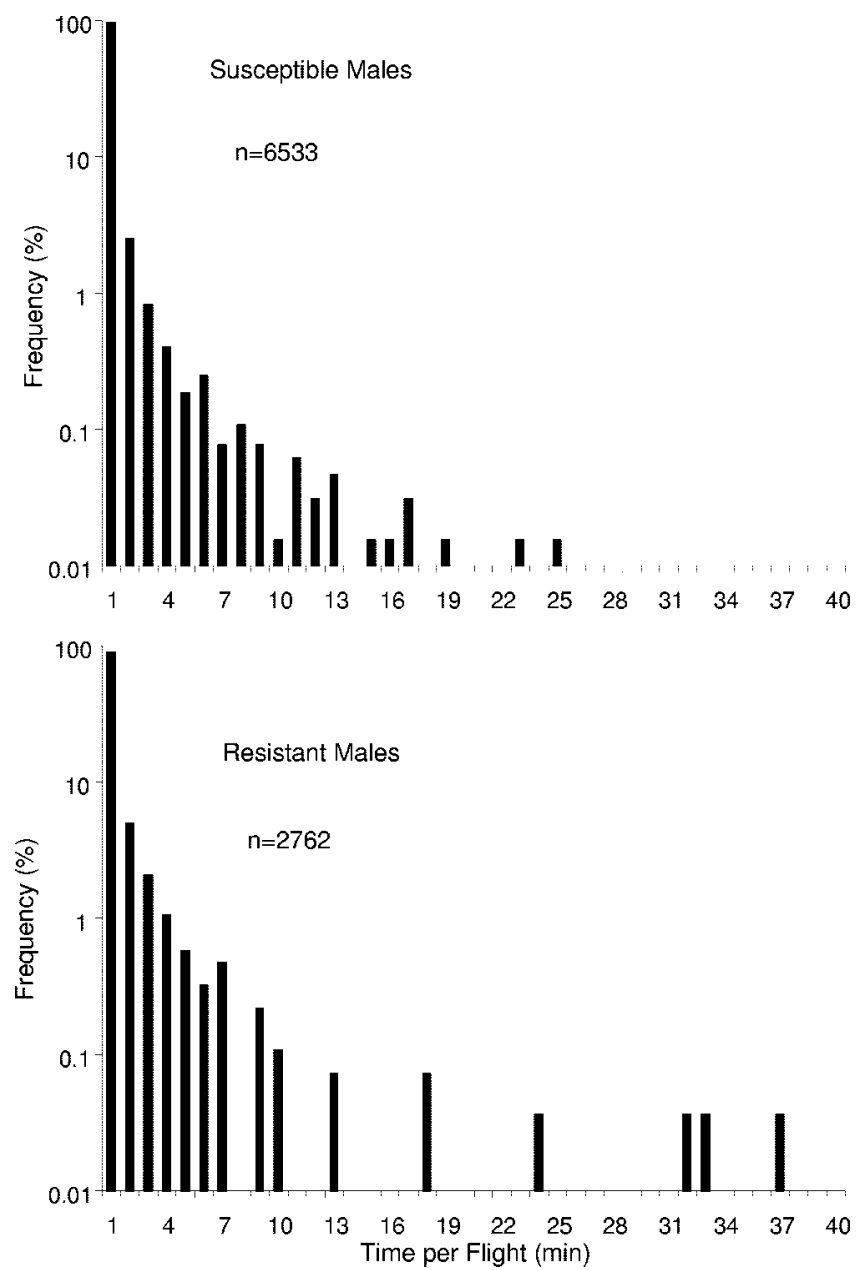

Fig. 2. Distributions of durations of all flights by susceptible $(n=54)$ and resistant $(n=34)$ male western corn rootworms. Note the logarithmic $y$-axis.

for all beetle groups. Sixteen (15\%; 15 female, one male) susceptible beetles undertook 23 sustained flights ranging from $20.3 \mathrm{~min}$ to $83 \mathrm{~min}$, whereas 18 (18\%; 16 female, two male) resistant beetles undertook 23 sustained flights ranging from 20.2 to 114 min.

In general, there were few significant differences in trivial or sustained flight parameters as affected by beetle population, age, or sex, and there were few significant interactions among variables (Table 1). The mean number of flights per beetle was significantly greater for the susceptible population than the resistant population (Table 2). This result seemed to be strongly influenced by the number of trivial flights per beetle $<1$ min in duration (Table 2 ).

Mean total flight time of female beetles was greater than that of male beetles (Table 2). This result was largely based on the significant increases in trivial flight time and number of trivial flights of females in comparison with males (Table 2). A similar trend was also apparent for female and male sustained flight, but results were not statistically significant (Table 2 ). The 95\% CIs around mean male (9.4, $48.0 \mathrm{~min})$ and mean female $(36.6,66.4 \mathrm{~min})$ sustained flight time overlapped which supports the ANOVA result. The large difference in sample size between males $(n=3)$ and females $(n=31)$ that engaged in sustained flight may have contributed to the statistical results obtained.

Both susceptible and resistant beetles exhibited increased frequencies of trivial flights taken per beetle as they aged (Table 2), which seemed to significantly influence the mean total flight time and to a lesser degree mean trivial flight time of older beetles (Tables 1 and 2). A significant interaction between main effects sex and age occurred for total number of flights and number of flights $<1 \mathrm{~min}$ (Table 1 ). In both cases, the number of female flights increased with age, whereas the number of male flights declined with age. Mean sustained flight time and the average number of sustained flights per beetle were not significantly affected by beetle age (Tables 1 and 2 ). Sixteen percent of 3- to 10-d-old beetles and 20\% of 11-20-d-old beetles engaged in at least one sustained flight.

Daily Flight Periodicity. Flights were recorded for a 23-h period beginning between 1100 and 1200 hours; 
Table 1. Experiment 1 analysis of variance

\begin{tabular}{|c|c|c|c|c|c|c|c|}
\hline \multirow{2}{*}{ Parameter } & \multirow{2}{*}{ Effect } & \multicolumn{3}{|c|}{ Initial analyses with interactions } & \multicolumn{3}{|c|}{ Follow-up main effects analyses } \\
\hline & & df & $F$ value & $P>F$ & df & $F$ value & $P>F$ \\
\hline \multirow{7}{*}{ Total no. of flights } & Age & 1,176 & 0.00 & 0.9950 & & & \\
\hline & Pop & 1,176 & 3.73 & 0.0260 & & & \\
\hline & Pop $\times$ age & 1,176 & 0.84 & 0.3607 & & & \\
\hline & Sex & 1,176 & 0.00 & 0.9592 & & & \\
\hline & Sex $\times$ age & 1,176 & 7.12 & 0.0083 & & & \\
\hline & Pop $\times$ sex & 1,176 & 1.61 & 0.2062 & & & \\
\hline & Pop $\times$ sex $\times$ age & 1,176 & 0.42 & 0.5163 & & & \\
\hline \multirow{7}{*}{ No. of flights $<1 \mathrm{~min}$} & Age & 1,176 & 0.06 & 0.8019 & & & \\
\hline & Pop & 1,176 & 3.16 & 0.0500 & & & \\
\hline & Pop $\times$ age & 1,176 & 0.94 & 0.3343 & & & \\
\hline & Sex & 1,176 & 0.04 & 0.8461 & & & \\
\hline & Sex $\times$ age & 1,176 & 6.84 & 0.0097 & & & \\
\hline & Pop $\times$ sex & 1,176 & 1.93 & 0.1662 & & & \\
\hline & Pop $\times$ sex $\times$ age & 1,176 & 0.37 & 0.5440 & & & \\
\hline \multirow{7}{*}{ No. of trivial flights $>1 \mathrm{~min}$} & Age & 1,129 & 4.11 & 0.0447 & 1,146 & 3.07 & 0.0492 \\
\hline & Pop & 1,129 & 0.04 & 0.8514 & 1,146 & 0.08 & 0.7761 \\
\hline & Pop $\times$ age & 1,129 & 0.54 & 0.4645 & & & \\
\hline & Sex & 1,129 & 1.89 & 0.1721 & 1,146 & 6.02 & 0.0153 \\
\hline & Sex $\times$ age & 1,129 & 0.57 & 0.4512 & & & \\
\hline & Pop $\times$ sex & 1,129 & 0.07 & 0.7941 & & & \\
\hline & Pop $\times$ sex $\times$ age & 1,129 & 0.19 & 0.6714 & & & \\
\hline \multirow[t]{7}{*}{ No. of sustained flights } & Age & 1,27 & 0.39 & 0.5361 & 1,30 & 1.13 & 0.2964 \\
\hline & Pop & 1,27 & 0.38 & 0.5424 & 1,30 & 0.33 & 0.5683 \\
\hline & Pop $\times$ age & 1,27 & 2.84 & 0.1035 & & & \\
\hline & Sex & 1,27 & 0.24 & 0.6298 & 1,30 & 0.67 & 0.4209 \\
\hline & Sex $\times$ age & 1,27 & 0.02 & 0.8855 & & & \\
\hline & Pop $\times$ sex & 1,27 & 0.02 & 0.8830 & & & \\
\hline & Pop $\times$ sex $\times$ age & & & & & & \\
\hline \multirow[t]{7}{*}{ Total flight time } & Age & 1,176 & 0.76 & 0.3835 & 1,201 & 3.15 & 0.0450 \\
\hline & Pop & 1,176 & 0.71 & 0.4001 & 1,201 & 1.17 & 0.2800 \\
\hline & Pop $\times$ age & 1,176 & 0.01 & 0.9219 & & & \\
\hline & Sex & 1,176 & 10.30 & 0.0016 & 1,201 & 12.49 & 0.0005 \\
\hline & Sex $\times$ age & 1,176 & 0.61 & 0.4340 & & & \\
\hline & Pop $\times$ sex & 1,176 & 0.14 & 0.7124 & & & \\
\hline & Pop $\times$ sex $\times$ age & 1,176 & 0.00 & 0.9852 & & & \\
\hline \multirow{7}{*}{ Trivial flight time } & Age & 1,129 & 2.91 & 0.0904 & 1,146 & 1.67 & 0.1921 \\
\hline & Pop & 1,129 & 0.01 & 0.9098 & 1,146 & 0.12 & 0.7293 \\
\hline & Pop $\times$ age & 1,129 & 0.97 & 0.3268 & & & \\
\hline & Sex & 1,129 & 4.09 & 0.0451 & 1,146 & 3.96 & 0.0484 \\
\hline & Sex $\times$ age & 1,129 & 0.07 & 0.7874 & & & \\
\hline & Pop $\times$ sex & 1,129 & 0.22 & 0.6371 & & & \\
\hline & Pop $\times$ sex $\times$ age & 1,129 & 1.15 & 0.2861 & & & \\
\hline \multirow[t]{7}{*}{ Sustained flight time } & Age & 1,27 & 0.42 & 0.5238 & 1,30 & 0.47 & 0.4972 \\
\hline & Pop & 1,27 & 0.03 & 0.8730 & 1,30 & 0.36 & 0.5518 \\
\hline & Pop $\times$ age & 1,27 & 1.77 & 0.1942 & & & \\
\hline & Sex & 1,27 & 0.35 & 0.5571 & 1,30 & 0.95 & 0.3368 \\
\hline & Sex $\times$ age & 1,27 & 0.16 & 0.6917 & & & \\
\hline & Pop $\times$ sex & 1,27 & 0.17 & 0.6840 & & & \\
\hline & Pop $\times$ sex $\times$ age & & & & & & \\
\hline
\end{tabular}

Pop, methyl-parathion-resistant vs. -susceptible colony.

The pop $\times$ sex $\times$ age interaction could not be calculated for number of sustained flights and sustained flight time because one susceptible male age group did not engage in sustained flight.

therefore, data between 1000 and 1200 hours were not included in the summaries. Generally, for each population, flight activity was greater during daylight; activity increased after first light and during early evening (Fig. 3).

Experiment 2: Flight Behavior of Resistant Beetles Exposed to a Sublethal Dose of Methyl-Parathion. A similar percentage of exposed and unexposed beetles flew at least once when tethered to the flight mill (exposed: 74.6\%, 103/138; control: 73.9\%, 88/119). This suggests that exposure to methyl-parathion did not adversely affect the number of beetles that would typically fly in a $23-\mathrm{h}$ period under standardized teth- ered conditions. After exposure to methyl-parathion, 78 resistant female beetles undertook 5,996 flights, compared with the control group of 68 female resistant beetles that undertook 5,526 flights (Fig. 4). Of these flights, the majority were $<1 \mathrm{~min}$ in duration $(85 \%$ for the control group and $90 \%$ for the exposed group). Less than $0.5 \%$ of all female flights were longer than the 20 min sustained flight minimum. Male flight distributions were similar to those exhibited by females (data not presented). Seventeen exposed beetles ( $17 \%$; 16 females, one male) engaged in 26 sustained flights ranging from 21.1 to $108 \mathrm{~min}$ in duration. Eighteen control beetles (19\%; 16 females, two males) 
Table 2. Tethered flight parameter (means \pm SE) comparisons for methyl-parathion-resistant and -susceptible western corn rootworms by population, sex, and age

\begin{tabular}{|c|c|c|c|c|c|c|}
\hline \multirow{3}{*}{ Flight parameters/beetle } & \multicolumn{6}{|c|}{ Main treatment effect } \\
\hline & \multicolumn{2}{|c|}{ Population } & \multicolumn{2}{|c|}{ Sex } & \multicolumn{2}{|c|}{ Age } \\
\hline & Susceptible & Resistant & Female & Male & $3-10 \mathrm{~d}$ & $11-20 \mathrm{~d}$ \\
\hline Total no. of flights & $88.8 \pm 8.0 \mathrm{a}$ & $66.1 \pm 8.1 b$ & $81.3 \pm 7.9 \mathrm{a}$ & $73.6 \pm 8.2 \mathrm{a}$ & $74.8 \pm 9.3 \mathrm{a}$ & $80.7 \pm 7.9 \mathrm{a}$ \\
\hline No. of flights $<1 \mathrm{~min}$ & $81.2 \pm 7.8 \mathrm{a}$ & $58.8 \pm 7.7 \mathrm{~b}$ & $72.2 \pm 7.6 \mathrm{a}$ & $68.6 \pm 8.0 \mathrm{a}$ & $69.6 \pm 9.2 \mathrm{a}$ & $71.4 \pm 7.4 \mathrm{a}$ \\
\hline No. of trivial flights $>1 \mathrm{~min}$ & $9.9 \pm 1.0 \mathrm{a}$ & $9.9 \pm 1.4 \mathrm{a}$ & $11.5 \pm 1.2 \mathrm{a}$ & $7.5 \pm 0.9 \mathrm{~b}$ & $7.1 \pm 1.1 b$ & $12.1 \pm 1.2 \mathrm{a}$ \\
\hline No. of sustained flights & $1.4 \pm 0.2 \mathrm{a}$ & $1.3 \pm 0.1 \mathrm{a}$ & $1.4 \pm 0.1 \mathrm{a}$ & $1.0 \pm 0.0 \mathrm{a}$ & $1.5 \pm 0.3 \mathrm{a}$ & $1.3 \pm 0.1 \mathrm{a}$ \\
\hline Total flight time (min) & $44.0 \pm 4.0 \mathrm{a}$ & $42.2 \pm 5.1 \mathrm{a}$ & $54.3 \pm 4.9 \mathrm{a}$ & $28.2 \pm 2.9 b$ & $37.7 \pm 4.9 b$ & $49.5 \pm 4.7 \mathrm{a}$ \\
\hline Trivial flight time ( $\min$ ) & $29.5 \pm 2.8 \mathrm{a}$ & $28.4 \pm 3.5 \mathrm{a}$ & $33.3 \pm 3.1 \mathrm{a}$ & $22.3 \pm 2.7 \mathrm{~b}$ & $22.4 \pm 3.7 \mathrm{a}$ & $33.4 \pm 3.0 \mathrm{a}$ \\
\hline Sustained flight time (min) & $45.3 \pm 7.5 \mathrm{a}$ & $52.7 \pm 11.1 \mathrm{a}$ & $51.5 \pm 7.3 \mathrm{a}$ & $28.7 \pm 4.5 \mathrm{a}$ & $56.1 \pm 9.4 \mathrm{a}$ & $45.9 \pm 9.0 \mathrm{a}$ \\
\hline
\end{tabular}

Means within main effect (i.e., population, sex, or age) and row followed by the same lowercase letter are not significantly different (SAS PROC GLM, $P>0.05$ ).

Total susceptible beetles, $n=108$; trivial flight, $n=81$; sustained flight, $n=16$; total resistant beetles, $n=98$; trivial flight, $n=70$; sustained flight, $n=18$; total female beetles, $n=118$; trivial flight, $n=91$; sustained flight, $n=31$; total male beetles, $n=88$; trivial flight, $n=60$; sustained flight, $n=3$; total beetles, $3-10$ d-old, $n=69$; trivial flight, $n=50$; sustained flight, $n=11$; total beetles, 11-20 d-old, $n=115$; trivial flight, $n=87$; sustained flight, $n=23$.

engaged in 30 sustained flights ranging from 20.4 to $126.4 \mathrm{~min}$.

There were few significant differences in flight parameters as affected by insecticide exposure, sex, or age, and there were no significant interactions among parameters (Table 3). Control beetles exhibited significantly greater mean total flight time, mean total trivial flight time, and mean number of trivial flights
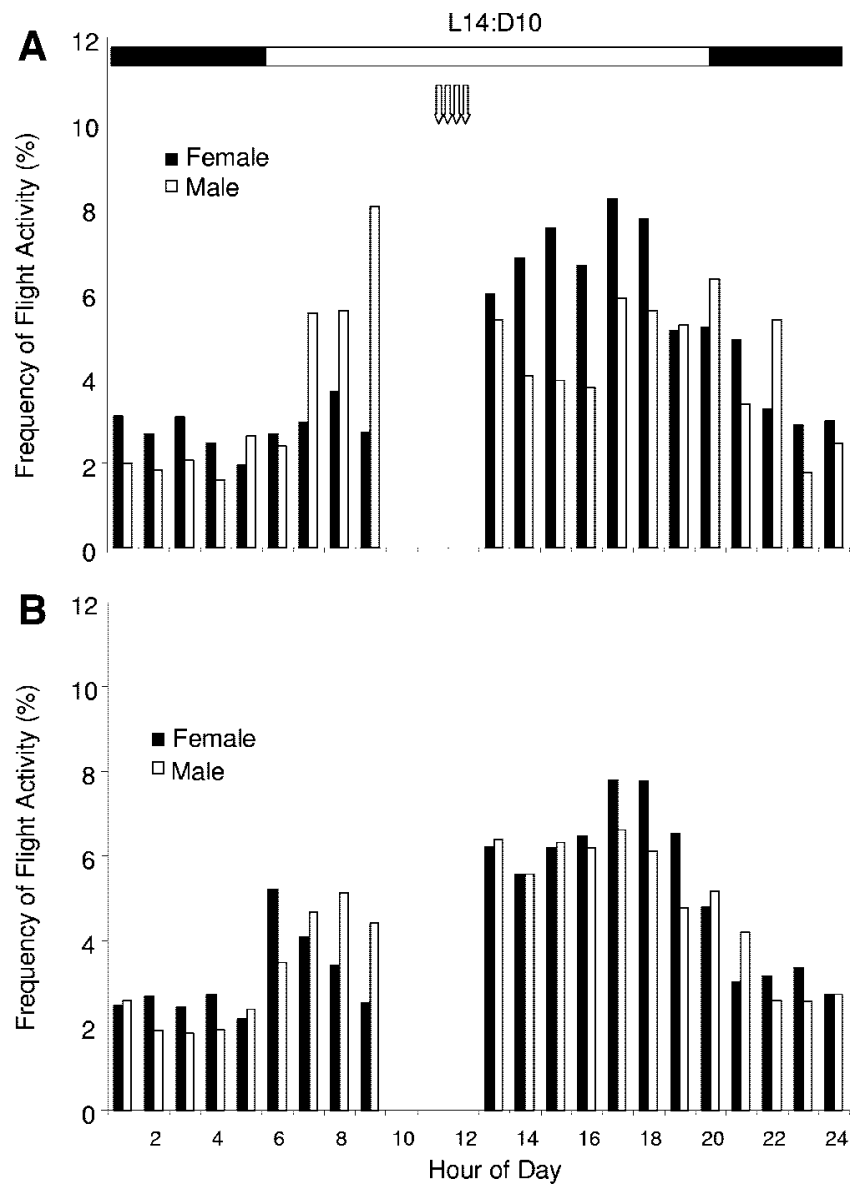

Fig. 3. Daily periodicity of western corn rootworm flights grouped by nearest hour of flight initiation. Horizontal bar represents photoperiod, arrows designate the period when experiments were initiated. (A) Resistant females $(n=64)$ and males $(n=34)$. (B) Susceptible females $(n=54)$ and males $(n=54)$. Tethered experiments were initiated at $\approx 1100$ hours and recorded for $23 \mathrm{~h}$; therefore, data between 1000 and 1200 hours are not available. 

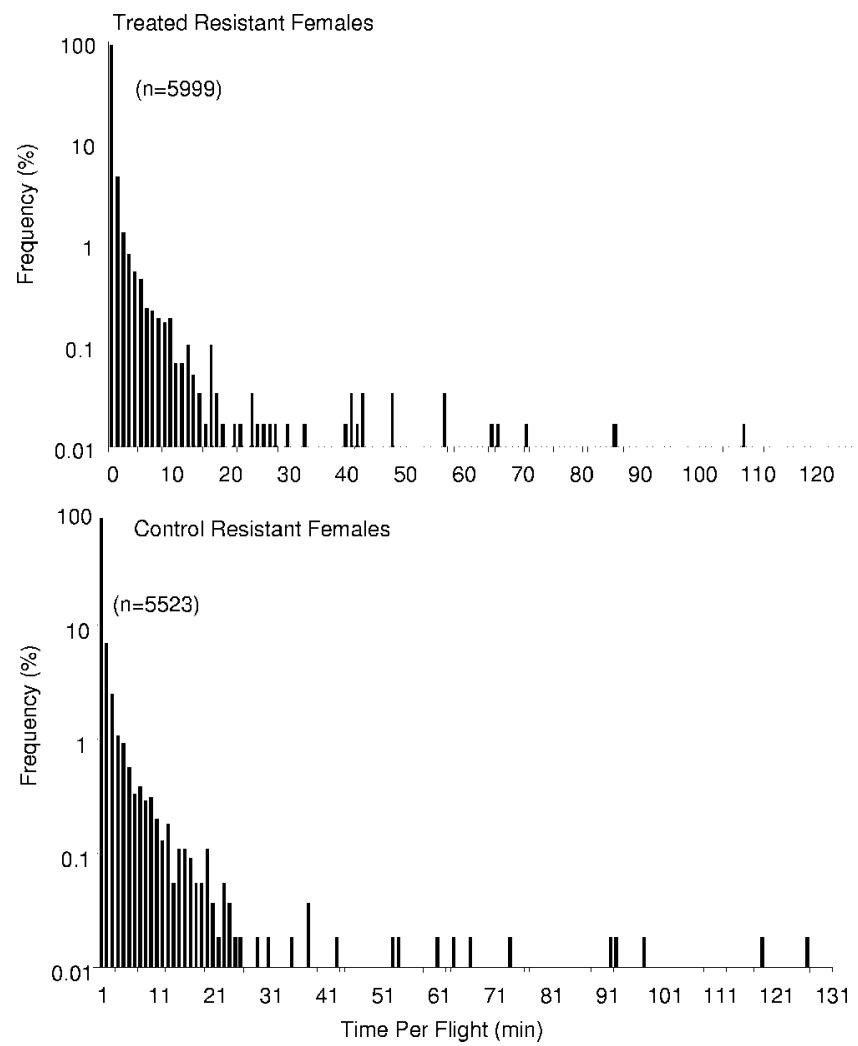

Fig. 4. Distributions of durations of all flights by resistant female western corn rootworm beetles exposed $(n=78)$ and unexposed $(n=68)$ to methyl-parathion. Note the logarithmic $y$-axis.

per beetle (Table 4). Female beetles across exposures flew twice as long as male beetles (Table 4). No other sex-related or any age-related significant differences were observed (Table 4), even though there was a large numerical difference between mean male and female sustained flight time (Table 4). However, in contrast to experiment 1 , the $95 \%$ CIs around mean sustained male (20.0, $54.4 \mathrm{~min}$ ) and female (57.0, 98.6 $\min$ ) flight times did not overlap, suggesting that the means were statistically different. Biological differences may have occurred between male and female sustained flight times in each experiment, but because male sustained flight was a rare event, larger male sample sizes would be needed to confirm or refute the observed trends.

Daily Flight Periodicity. Flights were recorded for a 23-h period beginning between 1100 and 1200 hours; data between 1000 and 1200 hours were not included in data summaries (Fig. 5). Generally, flight activity was greater during daylight hours with peaks of activity during mid-morning and early evening.

\section{Discussion}

The general characteristics of western corn rootworm flight dynamics as determined in this study are qualitatively similar to results of other studies conducted with this species. Tethered flight activity of $D$. v. virgifera individuals within populations was highly variable, and distributions of flight duration were skewed toward flights of relatively short duration (Figs. 1, 2, and 4). Both Coats et al. (1986) and Naranjo (1990) observed substantial variation among individuals and reported that only $15-24 \%$ of western corn rootworm adults engaged in flights $>20 \mathrm{~min}$. Results of this study and Naranjo (1990) document that both males and females can take sustained flights, but longrange flight behavior is much more commonly exhibited by females. These results, coupled with the trend that mean female flight time was longer than mean male flight time (Tables 2 and 4) are consistent with the observation that immigrant sex ratios are often highly skewed toward females in first-year cornfields (Godfrey and Turpin 1983). Flight activity was generally greater during the photophase than the scotophase in this study with activity increasing during mid-morning and early evening (Figs. 3 and 5). This daily periodicity activity pattern has been well documented in the laboratory (Coats et al. 1986, Naranjo 1990) and in the field (Witkowski et al. 1975, Grant and Seevers 1990, Isard et al. 2000).

The distribution of the duration of individual western corn rootworm flights was continuous in this study (Figs. 1, 2, and 4). This differs from previous tethered flight studies (Coats et al. 1986, Naranjo 1990) in 
Table 3. Experiment 2 analysis of variance

\begin{tabular}{|c|c|c|c|c|c|c|c|}
\hline \multirow{2}{*}{ Parameter } & \multirow{2}{*}{ Effect } & \multicolumn{3}{|c|}{ Initial analyses with interactions } & \multicolumn{3}{|c|}{ Follow-up main effects analyses } \\
\hline & & $\mathrm{df}$ & $F$ value & $P>F$ & $\mathrm{df}$ & $F$ value & $P>F$ \\
\hline \multirow[t]{7}{*}{ Total no. of flights } & Age & 1,183 & 0.00 & 0.9541 & 1,187 & 0.14 & 0.7066 \\
\hline & Pop & 1,183 & 0.04 & 0.8471 & 1,187 & 0.02 & 0.8963 \\
\hline & Pop $\times$ age & 1,183 & 1.37 & 0.2435 & & & \\
\hline & Sex & 1,183 & 0.09 & 0.7587 & 1,187 & 0.52 & 0.4717 \\
\hline & Sex $\times$ age & 1,183 & 0.13 & 0.7173 & & & \\
\hline & Pop $\times$ sex & 1,183 & 0.10 & 0.7525 & & & \\
\hline & Pop $\times$ sex $\times$ age & 1,183 & 2.60 & 0.1085 & & & \\
\hline \multirow[t]{7}{*}{ No. of flights $<1 \mathrm{~min}$} & Age & 1,183 & 0.04 & 0.8379 & 1,187 & 0.35 & 0.5550 \\
\hline & Pop & 1,183 & 0.14 & 0.7079 & 1,187 & 0.25 & 0.6166 \\
\hline & Pop $\times$ age & 1,183 & 0.59 & 0.2090 & & & \\
\hline & Sex & 1,183 & 0.01 & 0.9377 & 1,187 & 0.24 & 0.6226 \\
\hline & Sex $\times$ age & 1,183 & 0.14 & 0.7079 & & & \\
\hline & Pop $\times$ sex & 1,183 & 0.04 & 0.8504 & & & \\
\hline & Pop $\times$ sex $\times$ age & 1,183 & 2.52 & 0.1139 & & & \\
\hline \multirow[t]{7}{*}{ No. of trivial flights $>1 \mathrm{~min}$} & Age & 1,126 & 0.02 & 0.8895 & 1,130 & 0.19 & 0.6629 \\
\hline & Pop & 1,126 & 1.20 & 0.2762 & 1,130 & 5.36 & 0.0222 \\
\hline & Pop $\times$ age & 1,126 & 0.23 & 0.6334 & & & \\
\hline & Sex & 1,126 & 0.55 & 0.4594 & 1,130 & 0.44 & 0.5070 \\
\hline & Sex $\times$ age & 1,126 & 0.56 & 0.4576 & & & \\
\hline & Pop $\times$ sex & 1,126 & 0.18 & 0.6755 & & & \\
\hline & Pop $\times$ Sex $\times$ age & 1,126 & 0.76 & 0.3851 & & & \\
\hline \multirow[t]{7}{*}{ No. of sustained flights } & Age & 1,29 & 0.46 & 0.5048 & 1,31 & 0.38 & 0.5410 \\
\hline & Pop & 1,29 & 0.32 & 0.5749 & 1,31 & 0.29 & 0.5912 \\
\hline & Pop $\times$ age & 1,29 & 0.00 & 0.9786 & & & \\
\hline & Sex & 1,29 & 1.06 & 0.3108 & 1,31 & 1.71 & 0.2005 \\
\hline & Sex $\times$ age & & & & & & \\
\hline & Pop $\times$ sex & & & & & & \\
\hline & Pop $\times$ sex $\times$ age & & & & & & \\
\hline \multirow[t]{7}{*}{ Total flight time } & Age & 1,183 & 0.16 & 0.6896 & 1,187 & 0.06 & 0.7997 \\
\hline & Pop & 1,183 & 1.31 & 0.2544 & 1,187 & 4.11 & 0.0459 \\
\hline & Pop $\times$ age & 1,183 & 0.02 & 0.8749 & & & \\
\hline & Sex & 1,183 & 5.54 & 0.0196 & 1,187 & 7.27 & 0.0076 \\
\hline & Sex $\times$ age & 1,183 & 0.19 & 0.6596 & & & \\
\hline & Pop $\times$ sex & 1,183 & 0.44 & 0.5064 & & & \\
\hline & Pop $\times$ Sex $\times$ age & 1,183 & 0.05 & 0.8286 & & & \\
\hline \multirow[t]{7}{*}{ Trivial flight time } & Age & 1,126 & 0.16 & 0.6786 & 1,130 & 0.02 & 0.8804 \\
\hline & Pop & 1,126 & 2.85 & 0.0937 & 1,130 & 7.00 & 0.0092 \\
\hline & Pop $\times$ age & 1,126 & 0.31 & 0.5759 & & & \\
\hline & Sex & 1,126 & 1.67 & 0.1961 & 1,130 & 1.65 & 0.2009 \\
\hline & Sex $\times$ age & 1,126 & 0.16 & 0.6899 & & & \\
\hline & Pop $\times$ sex & 1,126 & 0.01 & 0.9157 & & & \\
\hline & Pop $\times$ sex $\times$ age & 1,126 & 0.06 & 0.8122 & & & \\
\hline \multirow[t]{7}{*}{ Sustained flight time } & Age & 1,29 & 0.39 & 0.5397 & 1,31 & 0.25 & 0.6193 \\
\hline & Pop & 1,29 & 0.82 & 0.3721 & 1,31 & 0.37 & 0.5462 \\
\hline & Pop $\times$ age & 1,29 & 0.42 & 0.5203 & & & \\
\hline & Sex & 1,29 & 0.55 & 0.4642 & 1,31 & 1.51 & 0.2284 \\
\hline & Sex $\times$ age & & & & & & \\
\hline & Pop $\times$ sex & & & & & & \\
\hline & Pop $\times$ sex $\times$ age & & & & & & \\
\hline
\end{tabular}

Pop = pop: methyl parathion exposed or unexposed resistant colony

Interactions between some main effects could not be calculated for no. of sustained flights and sustained flight time because some male age groups within each pop did not engage in sustained flight.

which the distributions of western corn rootworm flight times were clearly divided into two discrete periods, resulting in a bimodal pattern (flight duration $\approx 1-17$ min versus $\geq 30 \mathrm{~min}$ ). The reason for this difference is unclear, but it is unlikely the result of flight equipment differences because Naranjo (1990) used the same actograph and associated software that were used in this study. Western corn rootworm flight activity was characterized as trivial or sustained in the previous studies based in part on the bimodal flight duration pattern and also because flights $>30$ min have been defined as sustained flight in other insect studies (Dingle 1965, Rankin and Rankin 1980). It is interest- ing to note that some individuals in this study that did not engage in sustained flight ( $<20 \mathrm{~min}$ per flight) completed multiple trivial flights, resulting in a greater total flight time in a 23-h period than individuals completing a sustained flight. Depending upon the direction of the flights taken, the individuals completing only trivial flights could potentially exhibit significant net displacement from the starting point. Because there is a strong consensus among studies that $D . v$. virgifera long-range flight is a relatively uncommon event, short-to-medium duration flights may play an important role in determining the rate of gene flow and population spread in this species. 
Table 4. Tethered flight parameter (means \pm SE) comparisons for methyl-parathion resistant western corn rootworm beetles by insecticide exposure, sex, and age

\begin{tabular}{|c|c|c|c|c|c|c|}
\hline \multirow{3}{*}{ Flight parameters/beetle } & \multicolumn{6}{|c|}{ Main treatment effect } \\
\hline & \multicolumn{2}{|c|}{ Insecticide exposure } & \multicolumn{2}{|c|}{ Sex } & \multicolumn{2}{|c|}{ Age } \\
\hline & $\begin{array}{l}\text { MP-resistant } \\
\text { exposed }\end{array}$ & $\begin{array}{l}\text { MP-resistant } \\
\text { control }\end{array}$ & $\begin{array}{l}\text { Resistant } \\
\text { female }\end{array}$ & $\begin{array}{l}\text { Resistant } \\
\text { male }\end{array}$ & $3-10 \mathrm{~d}$ & $11-20 \mathrm{~d}$ \\
\hline Total no. of flights & $77.1 \pm 7.8 \mathrm{a}$ & $76.3 \pm 7.2 \mathrm{a}$ & $78.9 \pm 6.2 \mathrm{a}$ & $69.5 \pm 10.6 \mathrm{a}$ & $78.2 \pm 6.2 \mathrm{a}$ & $73.6 \pm 10.2 \mathrm{a}$ \\
\hline No. of flights $<1$ min & $70.0 \pm 7.6 \mathrm{a}$ & $65.6 \pm 6.4 \mathrm{a}$ & $69.4 \pm 5.8 \mathrm{a}$ & $66.2 \pm 10.1 \mathrm{a}$ & $70.0 \pm 6.0 \mathrm{a}$ & $63.8 \pm 9.4 \mathrm{a}$ \\
\hline No. of trivial flights $>1 \mathrm{~min}$ & $9.6 \pm 1.2 \mathrm{~b}$ & $14.5 \pm 1.7 \mathrm{a}$ & $12.3 \pm 1.2 \mathrm{a}$ & $10.2 \pm 1.9 \mathrm{a}$ & $11.8 \pm 1.2 \mathrm{a}$ & $12.0 \pm 1.9 \mathrm{a}$ \\
\hline No. of sustained flights & $1.5 \pm 0.2 \mathrm{a}$ & $1.7 \pm 0.2 \mathrm{a}$ & $1.7 \pm 0.2 \mathrm{a}$ & $1.0 \pm 0.0 \mathrm{a}$ & $1.7 \pm 0.2 \mathrm{a}$ & $1.5 \pm 0.2 \mathrm{a}$ \\
\hline Total flight time (min) & $46.7 \pm 5.8 b$ & $66.2 \pm 8.1 \mathrm{a}$ & $63.3 \pm 6.4 \mathrm{a}$ & $31.0 \pm 5.3 b$ & $56.0 \pm 6.3 \mathrm{a}$ & $54.9 \pm 9.0 \mathrm{a}$ \\
\hline Trivial flight time ( $\mathrm{min})$ & $31.8 \pm 4.0 \mathrm{~b}$ & $53.5 \pm 6.9 \mathrm{a}$ & $44.9 \pm 4.8 \mathrm{a}$ & $29.7 \pm 4.8 \mathrm{a}$ & $43.6 \pm 4.8 \mathrm{a}$ & $38.9 \pm 7.0 \mathrm{a}$ \\
\hline Sustained flight time (min) & $69.0 \pm 12.9 \mathrm{a}$ & $79.4 \pm 14.1 \mathrm{a}$ & $77.8 \pm 10.2 \mathrm{a}$ & $37.2 \pm 4.0 \mathrm{a}$ & $78.0 \pm 12.3 \mathrm{a}$ & $66.2 \pm 14.5 \mathrm{a}$ \\
\hline
\end{tabular}

Means within main effect and row followed by the same lowercase letter are not significantly different (SAS PROC GLM, $P>0.05$ ).

Methyl-parathion (MP)-exposed beetles, $n=103$; trivial flight, $n=72$; sustained flight, $n=17$; control beetles, $n=88$; trivial flight, $n=62$; sustained flight, $n=18$; total female beetles, $n=146$; trivial flight, $n=107$; sustained flight, $n=32$; total male beetles, $n=45$; trivial flight, $n=27$; sustained flight, $n=3$; total beetles, $3-10$ d-old, $n=128$; trivial flight, $n=85$; sustained flight, $n=24$; total beetles, $11-20 \mathrm{~d}$-old, $n=$ 63; trivial flight, $n=49$; sustained flight, $n=11$.

Exposure to methyl-parathion had a detrimental effect on flight behavior of resistant western corn rootworm populations in this study. Resistant beetles engaged in fewer flights, and total flight time per beetle was reduced after sublethal exposure to methyl-parathion. Sublethal effects of insecticides also have been shown to affect flight behavior in other insects. After 18-h exposure to aldicarb, both the green peach aphid, Myzus persicae (Sulzer), and the potato aphid, Macrosiphum euphorbiae (Thomas), lost their ability to fly (Boiteau et al. 1985). Alyokhin et al. (1999) reported that the Colorado potato beetle, Leptinotarsa decemlineata (Say), exhibited both a reduction in the number of flights and the proportion of individuals initiating flights after feeding on transgenic or Cry3A toxin-treated potato foliage. In contrast, Colorado potato beetles physiologically resistant to Cry3A toxin increased flight behavior after ingestion of Cry3A toxin, suggesting that both behavioral and physiological mechanisms may have enabled resistant individuals to survive exposure to the toxin (Alyokhin and Ferro 1999).

Trivial and sustained movement by the western corn rootworm has undoubtedly played a key role in the spread of organophosphate resistance in Nebraska. Although resistance was first identified in relatively isolated areas of Nebraska (Meinke et al. 1998, Zhou et al. 2002), the intensity of resistance has increased and the geographic distribution of resistance has expanded over time (Wright et al. 1998, 2001). As the distribution of resistance has changed, populations in transition areas that are in proximity to each other often exhibit highly variable susceptibility levels to methyl-parathion (i.e., field-to-field variation is very high, Wright et al. 1999, Zhou et al. 2002). Both male and female beetle movement may significantly affect the intensity and spread of resistance within and among fields, especially because methyl-parathion resistance is inherited as a semidominant trait (Parimi et al. 2003). Males emerge earlier than females (Meinke 1995) and female movement is very limited before mating (Coats et al. 1987); therefore, most females apparently mate within the field from which they emerged (Cates 1968, Quiring and Timmins 1990). In a segregating population (i.e., low-to-moderate frequency of resistant individuals), this tendency for mating to occur before dispersal could lead to increased intensity of resistance. Females generally mate only once, whereas males can mate multiple times during their lifetime (Branson et al. 1977). A large number of females may feed and oviposit in or near their field of origin but often make up a large proportion of beetles that emigrate and colonize new fields (Godfrey and Turpin 1983). Because of the semidominant nature of resistance inheritance, any mated resistant female that moves into a new field will spread the resistance gene(s). Likewise, resistant males that move into a nonresistant population will produce resistant offspring each time they mate.

Pest management practices are highly correlated with the rootworm susceptibility level in an area (Meinke et al. 1998). Adult resistance evolution has been found to occur primarily where adult spray programs are used versus areas where soil insecticides or crop rotation are the predominant management tactics. Actograph data indicate that in the absence of methyl-parathion exposure, susceptible individuals are more active than resistant individuals (i.e., take greater number of flights per beetle; Table 2), although both populations seem to have similar dispersal capabilities (no significant difference in total flight time; Table 2). After exposure to methyl-parathion, resistant populations have a great fitness advantage over susceptible populations (i.e., survival) but suffer a reduction in the number of flights and flight time per beetle. This tendency to reduce adult movement after exposure to methyl-parathion may be augmented by the landscape in the western Corn Belt where intensive irrigation practices and large field sizes provide an optimal environment for beetle survival and oviposition during hot summers. Although the potential influence of irrigation on western corn rootworm movement has not been experimentally addressed, another corn pest, the European corn borer, Ostrinia nubilalis (Hübner), has been shown to exhibit significantly less movement from irrigated fields 

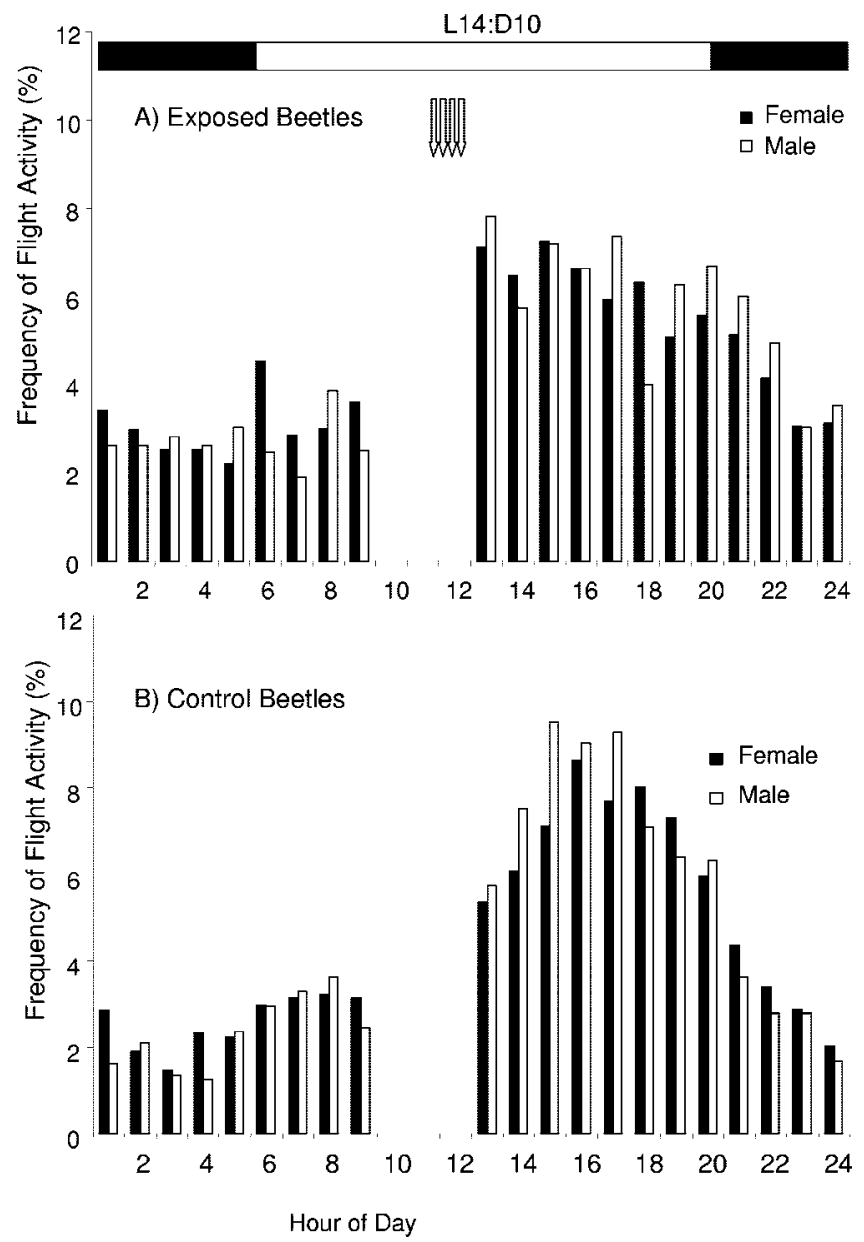

Fig. 5. Daily periodicity of flights grouped by nearest hour of flight initiation. Horizontal bar represents photoperiod, arrows designate the period when tethered experiments were initiated. (A) Resistant females $(n=78)$ and males $(n=25)$ exposed to methyl-parathion. (B) Resistant control females $(n=68)$ and males $(n=20)$ unexposed to methyl-parathion. Tethered experiments were initiated at $\approx 1100$ hours and recorded for $23 \mathrm{~h}$; therefore, data between 1000 and 1200 hours are not available.

than from dryland production fields (Hunt et al. 2001). These pest management and crop production factors collectively may lead to reduced beetle dispersal and subsequently to a greater proportion of the eggs laid in sprayed fields. The effect of these factors may be compounded over time because fields are often sprayed multiple times within and over consecutive seasons to reduce beetle densities that could contribute to localized increases in the intensity of selection and in frequency of resistant individuals.

In summary, data from this study suggest that organophosphate-resistant $D$. v. virgifera beetles can readily move and colonize new areas, but localized selection pressure (e.g., management practices) and exposure to methyl-parathion may contribute to the small-scale differences in resistance intensity often seen in the field.

\section{Acknowledgments}

We acknowledge Jim Brown and Rebecca Burke for beetle maintenance and laboratory assistance. This research was supported by the University of Nebraska Agricultural Experiment Station, USDA-ARS Specific Cooperative Agreement 58-5447-116, and USDA Initiative for Future Agricultural and Food Science (Grant 00 52103-9699). This is paper no. 14566 of the Journal Series of the University of Nebraska Agricultural Research Division and contribution no. 1183 of the Department of Entomology, University of Nebraska.

\section{References Cited}

Alyokhin, A., and D. N. Ferro. 1999. Modifications in dispersal and oviposition of Bt-resistant and Bt-susceptible Colorado potato beetles as a result of exposure to Bacillus thuringiensis subsp. tenebrionis Cry3A toxin. Entomol. Exp. Appl. 90: 93-101.

Alyokhin, A., D. N. Ferro, C. W. Hoy, and G. Head. 1999. Laboratory assessment of flight activity displayed by Colorado potato beetles (Coleoptera: Chrysomelidae) fed on transgenic and Cry3a toxin-treated potato foliage. J. Econ. Entomol. 92: 115-120. 
Ball, H. J., and G. T. Weekman. 1963. Differential resistance of corn rootworms to insecticides in Nebraska and adjoining states. J. Econ. Entomol. 56: 553-555.

Boiteau, G., R. R. King, and D. Levesque. 1985. Lethal and sublethal effects of aldicarb on two potato aphids (Homoptera: Aphidae): Myzus persicae (Sulzer) and Macrosiphum euphorbiae (Thomas). J. Econ. Entomol. 78: 41-44.

Branson, T. F., and E. E. Ortman. 1970. The host range of the western corn rootworm: further studies. J. Econ. Entomol. 63: 800-803.

Branson, T. F., P. L. Guss, and J. J. Jackson. 1977. Mating frequency of the western corn rootworm. Ann. Entomol. Soc. Am. 70: 506-508.

Cates, M. D. 1968. Behavioral and physiological aspects of mating and oviposition by the adult western corn rootworm, Diabrotica virgifera LeConte. Ph.D. dissertation, University of Nebraska, Lincoln, NE.

Chiang, H. C. 1973. Bionomics of the northern and western corn rootworms. Annu. Rev. Entomol. 18: 47-72.

Coats, S. A., J. J. Tollefson, and J. A. Mutchmor. 1986. Study of migratory flight in the western corn rootworm (Coleoptera: Chrysomelidae). Environ. Entomol. 15: 620-625.

Coats, S. A., J. A. Mutchmor, and J. J. Tollefson. 1987. Regulation of migratory flight by juvenile hormone mimic and inhibitor in the western corn rootworm (Coleoptera: Chrysomelidae). Ann. Entomol. Soc. Am. 80: 697-708.

Dingle, H. 1965. The relation between age and flight activity in the milkweed bug, Oncopeltus. J. Exp. Biol. 42: 269-283.

Godfrey, L. D., and F. T. Turpin. 1983. Comparison of western corn rootworm (Coleoptera: Chrysomelidae) adult populations and economic thresholds in first-year and continuous corn fields. J. Econ. Entomol. 76: 1028-1032.

Grant, R. H., and K. P. Seevers. 1989. Local and long range movements of adult western corn rootworm (Coleoptera: Chrysomelidae) as evidenced by washup along southern Lake Michigan shores. Environ. Entomol. 18: 266-272.

Grant, R. H., and K. P. Seevers. 1990. The vertical movement of adult western corn rootworms (Diabrotica virgifera virgifera) relative to the transport of momentum and heat. Agric. For. Met. 49: 191-203.

Hunt, T. E., L. G. Higley, J. F. Witkowski, L. J. Young, and R. L. Hellmich. 2001. Dispersal of adult European corn borer (Lepidoptera: Crambidae) within and proximal to corn. J. Econ. Entomol. 94: 1369-1377.

Isard, S. A., M. A. Nasser, J. L. Spencer, and E. Levine. 1999. The influence of weather on western corn rootworm flight activity at the borders of a soybean field in eastcentral Illinois. Aerobiologia 15: 95-104.

Isard, S. A., J. L. Spencer, M. A. Nasser, and E. Levine. 2000. Aerial movement of western corn rootworm (Coleoptera: Chrysomelidae): diel periodicity of flight activity in soybean fields. Environ. Entomol. 29: 226-234.

Jackson, J. J. 1985. Diabrotica spp. vol. 1, pp. 237-254. In P. Singh and R. F. Moore [eds.], Handbook of insect rearing. Elsevier Publishers, B.V., Amsterdam, The Netherlands.

Krysan, J. L., and R. F. Smith. 1987. Systematics of the virgifera species group of Diabrotica (Coleoptera: Chrysomelidae: Galerucinae). Entomography 5: 375-484.

Levine, E., and H. Oloumi-Sadeghi. 1991. Management of diabroticite rootworms in corn. Annu. Rev. Entomol. 36: 229-255.

Meinke, L. J. 1995. Adult corn rootworm management. Agricultural Resources Division, Institute of Agriculture and Natural Resources, University of Nebraska. MP63-C.

Meinke, L. J., B. Siegfried, R. Wright, and L. Chandler. 1997. Western corn rootworm resistance to insecticides: current situation in Nebraska, pp. 88-92. In Proceedings, Illinois Agricultural Pest Conference, January 1997, Urbana, IL.

Meinke, L. J., B. D. Siegfried, R. J. Wright, L.D. Chandler. 1998. Adult susceptibility of Nebraska populations of western corn rootworm to selected insecticides. J. Econ. Entomol. 91: 594-600.

Metcalf, R. L. 1983. Implications and prognosis of resistance to insecticides, pp. 703-733. In G. P. Georghiou and T. Saito [eds.], Pest resistance to pesticides. Plenum, New York.

Metcalf, R. L. 1986. Forward, pp vii-xv. In J. L. Krysan and T. A. Miller [eds.], Methods for the study of pest Diabrotica. Springer, New York.

Miota, F., M. E. Scharf, M. Ono, P. Marcon, L. Meinke, R. Wright, L. Chandler, and B. Siegfried. 1998. Mechanisms of methyl and ethyl parathion resistance in the western corn rootworm (Coleoptera: Chrysomelidae). Pestic. Biochem. Physiol. 61: 39-52.

Naranjo, S. E. 1990. Comparative flight behavior of $\mathrm{Di}$ abrotica virgifera virgifera and Diabrotica barberi in the laboratory. Entomol. Exp. Appl. 55: 79-90.

Naranjo, S. E. 1991. Influence of temperature and larval density on flight performance of Diabrotica virgifera virgifera LeConte (Coleoptera: Chrysomelidae). Can. Entomol. 123: 187-196.

Parimi, S., M. E. Scharf, L. J. Meinke, L. D. Chandler, and B. D. Siegfried. 2003. Inheritance of methyl-parathion resistance in Nebraska western corn rootworm populations (Coleoptera: Chrysomelidae). J. Econ. Entomol. 96: 131-136.

Quiring, D. T., and P. R. Timmins. 1990. Influence of reproductive ecology on feasibility of mass trapping $\mathrm{Di}$ abrotica virgifera virgifera (Coleoptera: Chrysomelidae). J. Appl. Ecol. 27: 965-982.

Rankin, S. M., and M. A. Rankin. 1980. The hormonal control of migratory flight behavior in the convergent ladybird beetle, Hippodamia convergens. Physiol. Entomol. 5: 175-182.

SAS Institute. 1998. SAS / STAT user's guide, version 6, 4 ed., vol. 2. SAS Institute, Cary, NC.

Scharf, M. E., L. J. Meinke, B. D. Siegfried, R. J. Wright, and L. D. Chandler. 1999. Carbaryl susceptibility, diagnostic concentration determination, and synergism for U. S. populations of western corn rootworm (Coleoptera: Chrysomelidae). J. Econ. Entomol. 92: 33-39.

Witkowski, J. F., J. C. Owens, and J. J. Tollefson. 1975. Diel activity and vertical flight distribution of adult western corn rootworms in Iowa cornfields. J. Econ. Entomol. 68: 351-352.

Wright, R. J., L. J. Meinke, and B. D. Siegfried. 1998. Adult western corn rootworm insecticide resistance in $\mathrm{Ne}$ braska. University of Nebraska, Cooperative Extension, NebFact NF 98-367.

Wright, R. J., L. J. Meinke, and B. D. Siegfried. 1999. Adult western corn rootworm insecticide resistance in $\mathrm{Ne}$ braska. University of Nebraska, Cooperative Extension, NebFact NF99-367.

Wright, R. J., L. J. Meinke, and B. D. Siegfried. 2001. Western corn rootworm insecticide resistance update, pp. 5961. In Proceedings, 2001 Crop Protection Clinics. Cooperative Extension, University of Nebraska, Lincoln.

Zhou, X., M. E. Scharf, S. Parimi, L. J. Meinke, R. J. Wright, L. D. Chandler, and B. D. Siegfried. 2002. Diagnostic assays based on esterase-mediated resistance mechanisms in western corn rootworm (Coleoptera: Chrysomelidae). J. Econ. Entomol. 95: 1261-1266.

Received 15 April 2004; accepted 8 April 2005. 
This article is the copyright property of the Entomological Society of America and may not be used for any commercial or other private purpose without specific written permission of the Entomological Society of America. 